
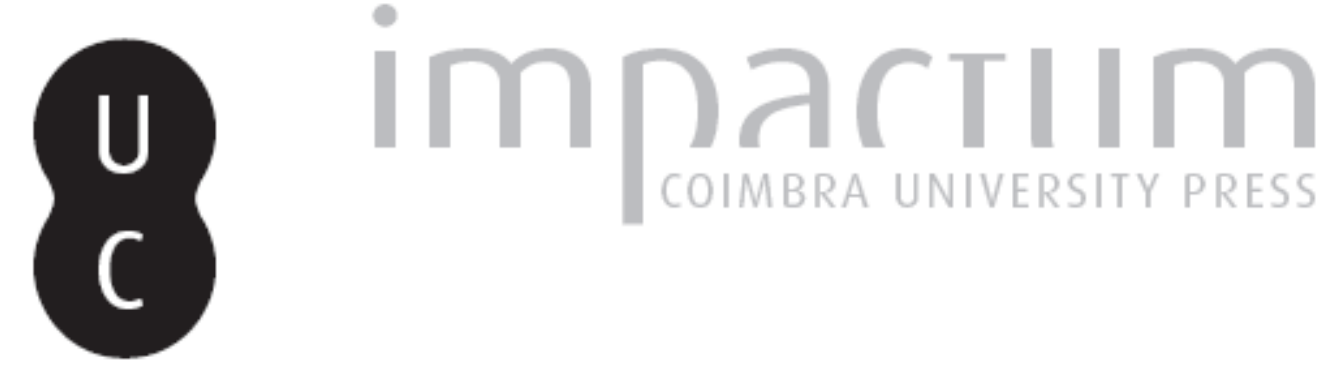

Biocombustíveis: uma política europeia ambiental e socialmente comprometida?

Autor(es): $\quad$ Nobre, Márcio Albuquerque

Publicado por: Centro de Informação Europe Direct de Aveiro; Centro de Estudos

Interdisciplinares do Século XX

URL

persistente:

URI:http://hdl.handle.net/10316.2/33986

DOI:

DOI:http://dx.doi.org/10.14195/1647-6336_11_15

Accessed : $\quad$ 26-Apr-2023 16:32:48

A navegação consulta e descarregamento dos títulos inseridos nas Bibliotecas Digitais UC Digitalis, UC Pombalina e UC Impactum, pressupõem a aceitação plena e sem reservas dos Termos e Condições de Uso destas Bibliotecas Digitais, disponíveis em https://digitalis.uc.pt/pt-pt/termos.

Conforme exposto nos referidos Termos e Condições de Uso, o descarregamento de títulos de acesso restrito requer uma licença válida de autorização devendo o utilizador aceder ao(s) documento(s) a partir de um endereço de IP da instituição detentora da supramencionada licença.

Ao utilizador é apenas permitido o descarregamento para uso pessoal, pelo que o emprego do(s) título(s) descarregado(s) para outro fim, designadamente comercial, carece de autorização do respetivo autor ou editor da obra.

Na medida em que todas as obras da UC Digitalis se encontram protegidas pelo Código do Direito de Autor e Direitos Conexos e demais legislação aplicável, toda a cópia, parcial ou total, deste documento, nos casos em que é legalmente admitida, deverá conter ou fazer-se acompanhar por este aviso.

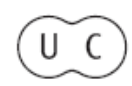


DEBATER

A EUROPA

jul-dez 2014

QUE EUROPA(S)?

CONTEXTOS E DESAFIOS 


\title{
Biocombustíveis: Uma política europeia ambiental e socialmente comprometida?
}

\author{
Márcio Albuquerque Nobre \\ Assistente-convidado da Faculdade de Direito \\ da Universidade de Coimbra \\ E-mail: albuquerquenobre@fd.uc.pt
}

\section{Resumo}

A promoção dos biocombustíveis, no contexto da União Europeia, foi desencadeada, no início do século XXI, pela Directiva dos Biocombustíveis. Todavia, os impactos ambientais e sociais desta política conduziram à sua revisão através da Directiva das Energias Renováveis e, até ao final de 2014, espera-se que sejam introduzidas novas alterações. O presente estudo procura fornecer uma visão geral da evolução do regime jurídico da produção e utilização dos biocombustíveis na União Europeia, concedendo particular atenção aos critérios de sustentabilidade ambiental e social. Por último, reflecte-se sobre o futuro da política de promoção de biocombustíveis enquanto política ambiental.

Palavras-Chave: biocombustíveis; critérios de sustentabilidade; desenvolvimento sustentável; sustentabilidade; energias renováveis

\begin{abstract}
The promotion of biofuels, in the context of the European Union, was triggered at the beginning of the 21 st century by the Biofuels Directive. However, the environmental and social impacts of this policy led to its amendment through the Renewable Energy Directive and, until the end of 2014 , new changes are expected. The present study seeks
\end{abstract}


to provide an overview of the evolution of the legal framework of the production and use of biofuels in the European Union, giving particular attention to environmental and social sustainability criteria. Lastly, this article analyses the future of biofuels promotion policy as environmental policy.

Keywords: biofuels; renewable energies; sustainability; sustainability criteria; sustainable development

\section{Dez anos de promoção de biocombustíveis na União}

\subsection{Descodificação do ADN da política europeia de biocombustíveis}

Um olhar desatento sobre a política energética europeia, em geral, e a política europeia de biocombustíveis, em particular, pode criar alguns equívocos e originar algumas conclusões precipitadas. ${ }^{1}$ Um dos equívocos é o de que a ausência de qualquer referência à política energética comum, antes do Tratado de Lisboa, significa que os Estados-membros ainda não se tinham confrontado com o problema da gestão racional dos recursos energéticos no passado. Outro dos mal-entendidos é o de que a política europeia de biocombustíveis é uma política eminentemente energética.

Para desfazer o primeiro equívoco, é importante recordar que o problema da gestão dos recursos energéticos foi um dos primeiros desafios enfrentados pelos países europeus na sequência do fim da Segunda Guerra Mundial. Numa Europa em que o carvão ainda representava uma fonte de energia importantíssima, a primeira das comunidades a ser criada foi exactamente a Comunidade Europeia do Carvão e do Aço (CECA). E, se o carvão estava destinado a tornar-se uma fonte de energia do passado, uma outra comunidade foi criada com os olhos postos no futuro: a Comunidade Europeia de Energia Atómica (Euratom). Para efeitos do presente estudo, não é relevante o escrutínio dos motivos que obstaram à consagração da política energética comum no Tratado que institui a Comunidade Económica Europeia $(\mathrm{CEE})^{2}$. Na verdade, um comité dirigido por Paul-Henri Spaak chegou a ser encarregado de esboçar propostas para um tratado no domínio da energia convencional, mas a consagração de

\footnotetext{
${ }^{1} \mathrm{O}$ presente estudo foi realizado no âmbito do projecto de investigação financiado pela Fundação para a Ciência e a Tecnologia através da Bolsa de Investigação com a referência SFRH/BD/77208/2011, financiada pelo POPH - QREN - Tipologia 4.1 - Formação Avançada, comparticipado pelo Fundo Social Europeu e por fundos nacionais do MEC.

${ }^{2}$ Para uma análise deste assunto, consultar o brilhante estudo de LUCAS, N. J. D. - Energy and the European Communities. London: Europa Publications, 1977, pp. 16 e ss.
} 
uma política energética comum acabou por não se verificar ${ }^{3}$. Em todo o caso, fica demonstrado que, ao contrário do que alguns autores entendem ${ }^{4}$, os Estados-membros já foram confrontados com o desafio da gestão racional de recursos energéticos no passado.

O segundo mal-entendido é um pouco mais difícil de esclarecer porque, para determinar a filiação da política europeia de biocombustíveis, já não nos chegará o recurso à história da construção europeia, afigurando-se também necessário o amparo de uma comparação transatlântica. Com efeito, foi no Brasil e nos Estados Unidos da América que o fenómeno da produção e utilização em massa de biocombustíveis se iniciou. Nestes países, a promoção dos biocombustíveis foi desencadeada sobretudo pela necessidade de responder à crise energética gerada na sequência dos sucessivos choques petrolíferos dos anos 70. Não se desprezaram outros objectivos como, por exemplo, o apoio ao sector agrícola, mas o principal escopo das políticas brasileira e norte-americana foi, pelo menos numa primeira fase, a salvaguarda da segurança energética. Neste contexto, foram aprovados o Programa Nacional do Álcool (ProÁlcool) brasileiro ${ }^{5}$ - que visava promover a produção de álcool a partir de cana-deaçúcar, mandioca ou de outro "insumo" -, e o Energy Tax Act de 1978 norte-americano - que previa isenções fiscais para os combustíveis que incorporassem uma percentagem mínima de $10 \%$ de etanol $^{6}$.

\footnotetext{
${ }^{3}$ Cfr. LuCAS, N. J. D. - Energy and the European Communities..., pp. 12-15.

${ }^{4}$ Manifestando este entendimento, cfr. C GOMES, C. A. - Regulação dos Biocombustíveis na Comunidade Europeia. In FERREIRA, H. S.; LEITE, J. R. M. - Biocombustíveis - fonte de energia sustentável?: considerações jurídicas, técnicas e éticas. São Paulo: Editora Saraiva, 2010, pp. 195.

${ }^{5}$ O ProÁlcool foi aprovado pelo Decreto n. $.^{\circ} 76.593 / 75$. O art. 1. ${ }^{\circ}$ deste diploma não deixa dúvidas quanto ao escopo energético da política brasileira de biocombustíveis: "Fica instituído o Programa Nacional doÁlcool visando ao atendimento das necessidades do mercado interno e externo e da política de combustíveis automotivos".

Deve salientar-se, todavia, que o Brasil já havia adoptado algumas medidas de promoção da utilização dos biocombustíveis anteriores ao ProÁlcool: (i) em 1903 foram adoptadas recomendações para a implantação de infra-estruturas para a produção de bioetanol; e (ii) em 1931 foi emanado o Decreto n. ${ }^{\circ}$ 19.717/31 que já consagrava uma obrigação de incorporar, pelo menos, $5 \%$ de etanol anidro na gasolina importada.

Para uma análise do regime jurídico do sector dos biocombustíveis no Brasil, cfr. MORAES, R. J. - Setor Sucroalcooleiro: regime jurídico ambiental das usinas de açúcar e álcool. São Paulo: Editora Saraiva, 2011; FerreiRA, M. L. P. C.; Ayala, P. A. - A Regulação dos Biocombustíveis no Âmbito Federal. In FERREIRA, H. S.; LEITE, J. R. M. - Biocombustíveis - fonte de energia sustentável?: considerações jurídicas, técnicas e éticas. São Paulo: Editora Saraiva, 2010, pp. 96-119; FARIAS, T. - A Regulação dos Biocombustíveis no Âmbito Estadual. In FERREIRA, H. S.; LEITE, J. R. M. - Biocombustíveis - fonte de energia sustentável?: considerações jurídicas, técnicas e éticas. São Paulo: Editora Saraiva, 2010, pp. 120-137.

${ }^{6}$ A predominância do objectivo energético pode comprovar-se através da leitura do título desta lei: "An act to provide tax incentives for the production and conservation of energy, and for other purposes".
} 
Comparada com as políticas do Brasil e dos Estados Unidos da América, pode dizer-se que a política de promoção de biocombustíveis da União Europeia é relativamente recente. Ao contrário das primeiras, que surgem logo nos anos 70, a política europeia de biocombustíveis só se iniciou no século XXI. Esta diferença de idade tem consequências importantes. Nascida num ambiente completamente diferente daquele em que brotaram as políticas do Brasil e dos Estados Unidos da América, a política europeia de biocombustíveis assume uma natureza distinta. A promoção dos biocombustíveis no Brasil e nos Estados Unidos germinou num clima de medo perante eventuais rupturas no fornecimento de energia. Diferentemente, a promoção dos biocombustíveis insere-se no âmbito de uma resposta ao medo das alterações climáticas, tendo como principal objectivo o cumprimento das metas previstas no Protocolo de Quioto $^{7}$.

Em termos sintéticos, pode dizer-se que enquanto a política dos Estados Unidos e do Brasil é uma política predominantemente energética - o principal objectivo da promoção dos biocombustíveis é assegurar o aprovisionamento energético através do aumento e diversificação das fontes de energia, apesar de não se ignorarem outros objectivos como o desenvolvimento do sector agrícola -, a política da União Europeia é uma política predominantemente ambiental - apesar de não se desprezar o objectivo de assegurar o aprovisionamento energético e de desenvolver o sector agrícola, o principal escopo da promoção dos biocombustíveis é a redução das emissões de gases com efeito de estufa.

Em abono desta posição, avançamos mais alguns argumentos. Em primeiro lugar, tanto a Directiva 2003/30/CE do Parlamento Europeu e do Conselho, de 8 de Maio de 2003, relativa à promoção da utilização de biocombustíveis ou de outros combustíveis renováveis nos transportes (Directiva dos Biocombustíveis), como a Directiva 2009/28/CE do Parlamento Europeu e do Conselho, de 23 de Abril de 2009, relativa à promoção da utilização de energia proveniente de fontes renováveis que altera e subsequentemente revoga as Directivas 2001/77/CE e 2003/30/CE (Directiva das Energias Renováveis), foram aprovadas ao abrigo do art. $174 .^{\circ}$ do Tratado da Comunidade Europeia, que consagrava a política da Comunidade no domínio do

\footnotetext{
A promoção dos biocombustíveis nos Estados Unidos foi, recentemente, reforçada através de outros actos normativos como o Clean Energy Act de 1992, o Energy Policy Act de 2005 e o Energy Independence and Security Act de 2007.

${ }^{7}$ O Protocolo de Quioto fixou a meta de redução mínima de 5\% das emissões de gases com efeito de estufa até 2012 nos países industrializados (art. 3.\%1).
} 
ambiente (corresponde ao actual art. 191..$^{\circ}$ do Tratado sobre o Funcionamento da União Europeia, de acordo com o Tratado de Lisboa). Reconhecemos, no entanto, que este argumento é frágil porque, no momento em que ambas as directivas foram aprovadas, a política energética ainda não tinha sido consagrada enquanto política da União Europeia $^{8}$. Esta objecção remete-nos para o segundo argumento: a actual proposta de alteração da Directiva das Energias Renováveis apresentada pela Comissão Europeia baseia-se no art. $192 .^{\circ}$ do Tratado sobre o Funcionamento da União Europeia e declara expressamente que o seu principal objectivo é a protecção do ambiente ${ }^{9}$. Isto significa que a Comissão Europeia considera que a política europeia de biocombustíveis é uma política ambiental que se subsume no Título XX - O Ambiente (arts. $191 .^{\circ}$ a 193..$^{\circ}$ ) e não uma política energética nos termos do Título XXI - A Energia (arts. 194. ${ }^{\circ}$ ). E, neste caso, não vale a objecção invocada acima porque a política energética já se encontrava consagrada enquanto política da União no momento em que se iniciou o procedimento de alteração da Directiva das Energias Renováveis.

A estes argumentos de índole formal junta-se um outro de natureza substancial: com a aprovação da Directiva das Energias Renováveis, só os biocombustíveis sustentáveis, ou seja, aqueles cuja produção e utilização permite uma melhoria do ambiente, podem ser contabilizados para efeitos do cumprimento das metas estabelecidas pela União Europeia em matéria de energias renováveis e beneficiar de eventuais regimes de apoio (cfr. infra 1.3. Viragem rumo à sustentabilidade). Mais uma vez, torna-se evidente a supremacia dos objectivos ambientais: a política europeia de promoção dos biocombustíveis visa essencialmente a obtenção de frutos no campo ambiental, ainda que da mesma possam resultar frutos na ceara energética ou agrícola.

Finalmente, vale a pena reproduzir a argumentação do Tribunal de Justiça num caso controverso em que esta instância dedicou algumas considerações ao problema de saber qual é o principal objectivo das medidas de promoção das energias renováveis:

"a utilização de fontes de energia renováveis para a produção de electricidade, que se destina a promover uma regulamentação como a Stromeinspeisungsgesetz, alterada, é útil para a protecção do ambiente, na medida em que contribui para a redução das

\footnotetext{
${ }^{8}$ A consagração da política energética, enquanto política da União Europeia, só se verificou com o Tratado de Lisboa, de 13 de Dezembro de 2007: art. 194. ${ }^{\circ}$ do Tratado sobre o Funcionamento da União Europeia.

${ }^{9}$ Cfr. COM (2012) 595 final, 17.12.2012, Proposta de Directiva do Parlamento Europeu e do Conselho que altera a Directiva 98/70/CE relativa à qualidade da gasolina e do combustível para motores a diesel e a Directiva 2009/28/CE relativa à promoção da utilização de energia proveniente de fontes renováveis (Proposta da Comissão), p. 5.
} 
emissões de gases com efeito de estufa que se encontram entre as principais causas das alterações climáticas que a Comunidade Europeia e os seus Estados-Membros se comprometeram a combater.

$(\ldots)$

A isto acresce que, como resulta do artigo $130 .^{\circ}-\mathrm{R}, \mathrm{n} .{ }^{\circ} 2$, primeiro parágrafo, terceiro período, do Tratado CE (que passou, após alteração, a artigo $174 .^{\circ}$, n. ${ }^{\circ}$ 2, primeiro parágrafo, CE), as exigências em matéria de protecção do ambiente devem ser integradas na definição e execução das demais políticas da Comunidade. $(\ldots)$

Resulta, aliás, expressamente do vigésimo oitavo considerando da Directiva 96/92 que é «por razões de protecção do ambiente» que esta, nos seus artigos $8 .^{\circ}, \mathrm{n} .{ }^{\circ} 3$, e $11 .^{\circ}, \mathrm{n} .^{\circ} 3$, autoriza os Estados-Membros a privilegiarem a produção de electricidade a partir de fontes de energia renováveis" (sublinhado nosso) ${ }^{10}$.

O trecho que acabámos de transcrever não deixa margem para grandes dúvidas: o entendimento do Tribunal de Justiça é o de que a protecção do ambiente é o principal objectivo das políticas de promoção das energias renováveis. Tendo em conta que os biocombustíveis são uma fonte de energia renovável, estas considerações não podem deixar de se aplicar a qualquer política que os promova.

\subsection{Origem da política}

\subsubsection{Precedentes}

Apesar de a política europeia de promoção de biocombustíveis só se ter iniciado no século XXI, isso não significa que não tenham existido alguns precedentes que favoreceram o desenvolvimento deste sector ${ }^{11}$.

\footnotetext{
${ }^{10}$ Cfr. Acórdão do Tribunal de Justiça, de 13 de Março de 2001, no processo C-379/98, PreussenElektra contra Schleswag.

$11 \mathrm{O}$ presente estudo só se refere às medidas adoptadas pela União Europeia e não às medidas eventualmente adoptadas por cada Estado-membro, antes de se ter iniciado a política europeia de biocombustíveis. Na França, por exemplo, a utilização de biocombustíveis precedeu a política europeia de biocombustíveis. Alguns autores mencionam a utilização de biocombustíveis misturados com gasolina em autocarros parisienses no período que antecede a Primeira Guerra Mundial e recordam a existência de uma obrigação de incorporação de etanol na gasolina que condicionava a importação de petróleo bruto (cfr. BALlerini, D.; AlAZARD-TouX, N. - Les Biocarburants: état des lieux, perspectives et enjeux du developpement. Paris: Editions Technip, 2006, p. 2.). Além disso, a partir dos anos 80, o Estado francês aumentou a sua intervenção neste sector através do Plan CARBUROL e do Plan Hervé (para uma descrição destes planos, cfr. SCARWELL, H-J. - Biocarburants: les temps changent! Effet d'annonce ou réelle avancée?. Villeneuve d'Ascq: Presses Universitaires du Septentrion, 2007, pp. 96-101 ).
} 
Em rigor, o primeiro episódio de que temos conhecimento é um estudo sobre a fileira do etanol, iniciado pela Comissão Europeia, em Novembro de $1979^{12}$. Curiosamente, apesar de na época a Comissão chegar à conclusão de que este tipo de biocombustíveis poderia, eventualmente, ser uma solução parcial para o problema da dependência energética em relação aos combustíveis fósseis, a verdade é que o relatório foi desencadeado por uma questão de natureza distinta que já se colocava na época: como responder aos excedentes agrícolas $?^{13}$ Esta questão foi retomada no Livro Verde, de Julho de 1985, sobre as perspectivas para a Política Agrícola Comum ${ }^{14}$, em que se analisou a possibilidade de canalizar os excedentes agrícolas para a produção de biocombustíveis, sendo os agricultores compensados, total ou parcialmente, pela diferença entre o preço de oferta e o preço de venda ${ }^{15}$. Neste contexto, em 1986, foi adoptado um regulamento em que se previa a concessão de apoios às colheitas de cereais que fossem afectadas a novas utilizações industriais ${ }^{16}$. Este acto normativo não foi, contudo, objecto de um regulamento de execução, o que implicou a sua absoluta ineficácia $^{17}$.

As primeiras medidas de promoção do sector dos biocombustíveis acabariam, assim, por surgir no domínio energético ${ }^{18}$. A aprovação da Directiva 85/210/CEE do Conselho, de 20 de Março de 1985, relativa à aproximação das legislações dos Estadosmembros respeitantes ao teor de chumbo na gasolina, abriu a porta à emergência de outros aditivos da gasolina, entre os quais se incluem alguns tipos de biocombustíveis como, por exemplo, o etanol ${ }^{19}$. E, no mesmo ano, foi aprovada a Directiva 85/536/CEE do Conselho, de 5 de Dezembro de 1985, relativa às economias de petróleo bruto realizáveis através da utilização de compostos de combustíveis de substituição, que estabelecia o seguinte: “ Os Estados-membros não impedirão, não restringirão, nem desencorajarão, por razões que se prendam com o teor em compostos oxigenados, a produção, a comercialização e a livre circulação de misturas de gasolina contendo compostos oxigenados orgânicos que estejam em conformidade com o anexo e que não

\footnotetext{
${ }^{12}$ Cfr. SCARWELL, H-J. - Biocarburants: les temps changent..., p. 101.

${ }^{13}$ Cfr. SCARWELL, H-J. - Biocarburants: les temps changent..., p. 102.

${ }^{14}$ COM (85) 333 final, 15.07.1985, Perspectivas para a Política Agrícola Comum.

${ }^{15}$ Cfr. SCARWELL, H-J. - Biocarburants: les temps changent..., pp. 114-115.

${ }^{16}$ Cfr. art. 11. ${ }^{\circ}$ do Regulamento CEE n. ${ }^{\circ} 1579 / 86$ do Conselho, de 23 de Maio de 1986, que altera o Regulamento CEE n. ${ }^{\circ}$ 2727/75, que estabelece a organização comum de mercado no sector dos cereais.

${ }^{17}$ Cfr. SCARWELL, H-J. - Biocarburants: les temps changent..., pp. 116-117.

18 Neste sentido, cfr. DelvauX, B. - Promoting Biofuels in Energy Supply: the European Legal Framework. European Environmental Law Review, vol. 3, n. ${ }^{\circ}$ 3, March, 2004, p. 68.

${ }^{19}$ Cfr. SCARWELL, H-J. - Biocarburants: les temps changent..., p. 115.
} 
ultrapassem os limites que figuram no ponto II da coluna A, do referido anexo" (art. 1. $\left.{ }^{\circ}\right)$. Conjugando este preceito com o anexo, facilmente concluímos que o etanol é um dos compostos oxigenados orgânicos que podem ser misturados à gasolina. Mais tarde, a possibilidade de incorporar biocombustíveis na gasolina e no gasóleo foi regulamentada pela Directiva 98/70/CE do Parlamento Europeu e do Conselho, de 13 de Outubro de 1998, relativa à qualidade da gasolina e do combustível para motores a diesel e que altera a Directiva 93/12/CEE do Conselho.

Regressando ao âmbito da Política Agrícola Comum, só com a reforma operada em 1992 se adoptaram medidas que favoreceram o desenvolvimento do sector dos biocombustíveis: passaram a conceder-se apoios não só às superfícies que tivessem de ficar em pousio, mas também às superfícies ocupadas com culturas não alimentares, entre as quais se incluíam culturas destinadas à produção de biocombustíveis ${ }^{20}$.

\subsubsection{Directiva dos Biocombustíveis}

Atendendo aos precedentes da política europeia de biocombustíveis, seria de esperar que ela fosse enxertada na política agrícola comum ou na política energética europeia. Mas não foi isso que sucedeu. Como referimos acima (cfr. supra 1.1. Descodificação do ADN da política europeia de biocombustíveis) a promoção dos biocombustíveis na União Europeia insere-se no contexto do cumprimento das metas previstas no Protocolo de Quioto, filiando-se no âmbito da política ambiental comum.

Deste modo, na sequência de uma Comunicação da Comissão Europeia de $2001^{21}$, foram aprovadas duas directivas no sentido de promover a produção e utilização dos biocombustíveis na União Europeia. A primeira foi a Directiva dos Biocombustíveis, que impôs aos Estados-membros da União que colocassem no mercado uma proporção mínima de biocombustíveis. Cada Estado-membro conservava a liberdade de estabelecer as metas nacionais ${ }^{22}$, sendo apenas fixados os seguintes valores de referência: numa primeira fase, o valor de referência era de $2 \%$ de toda a gasolina e de todo o gasóleo colocado no mercado para utilização no sector dos transportes até 31 de

\footnotetext{
${ }^{20}$ Cfr. BALlerini, D.; AlAZARD-TouX, N. - Les Biocarburants: état des lieux, perspectives et enjeux du developpement..., pp. 16-17 ; SCARWELL, H-J. - Biocarburants: les temps changent..., p. 121.

${ }^{21} \mathrm{COM}$ (2001) 547 final, 7.11.2001, relativa a combustiveis alternativos para os transportes rodoviários e a um conjunto de medidas destinadas a promover a utilização de biocombustíveis.

${ }^{22}$ A determinação da natureza indicativa ou obrigatória das metas foi um aspecto que gerou alguma controvérsia. A proposta de directiva original impunha metas obrigatórias, mas a versão definitiva da directiva limitou-se a estabelecer valores de referência. A este propósito, cfr. DELVAUX, B. - Promoting Biofuels in Energy Supply..., p. 73.
} 
Dezembro de 2005; posteriormente, o valor de referência subiria para os 5,75\% até 31 de Dezembro de $2010^{23}$. Apesar de não se tratar de metas obrigatórias, existindo apenas uma obrigação moral de os Estados-membros atingirem os níveis de utilização de biocombustíveis a que se haviam proposto ${ }^{24}$, os Estados-membros tinham o dever de informar a Comissão sobre as medidas adoptadas para as alcançar.

Os medidas a adoptar para atingir as metas nacionais instituídas ficavam à discricionariedade de cada Estado-membro, devendo, no entanto, respeitar as orientações da Comissão em matérias de auxílios estatais a favor do ambiente ${ }^{25}$. Numa primeira fase, as principais medidas de fomento da produção e utilização de biocombustíveis foram os incentivos de natureza fiscal. Neste domínio, assumiu particular importância a aprovação da Directiva 2003/96/CE do Conselho, de 27 de Outubro de 2003, que reestrutura o quadro comunitário de tributação dos produtos energéticos e da electricidade, pois foi através dela que se enquadrou a possibilidade de se estabelecerem isenções parciais ou totais de impostos especiais sobre os biocombustíveis $^{26}$.

As medidas de promoção adoptadas pelos Estados-membros não foram, contudo, suficientes para atingir as ambiciosas metas fixadas pela União Europeia através do recurso a matérias-primas endógenas. Os Estados-membros viram-se, por isso, forçados a recorrer a importações de outras regiões do globo com o objectivo de atingirem os níveis de utilização de biocombustíveis a que se haviam proposto. Este recurso à produção externa é mais um dos aspectos em que a política europeia de biocombustíveis se distingue das políticas brasileira e norte-americana, cujo enfoque incide na produção interna. O Brasil e os Estados Unidos podem ter sido pioneiros na produção e utilização em massa dos biocombustíveis, mas foi a União Europeia que globalizou este sector, criando um mercado internacional de biocombustíveis.

A globalização do sector dos biocombustíveis acarretou, todavia, uma globalização dos próprios riscos que lhe são inerentes. E foram, sem dúvida, os países menos

\footnotetext{
${ }^{23}$ Cfr. art. 3. ${ }^{\circ}$ da Directiva dos Biocombustíveis.

${ }^{24}$ COM (2006) 845 final, 10.01.2007, Relatório sobre o Progresso em Biocombustíveis, p. 5.

25 Nesta época, aplicavam-se as orientações que a Comissão Europeia estabeleceu no Enquadramento comunitário dos auxílios estatais a favor do ambiente (2001/C 37/03). Este documento foi revisto em 2008, tendo sido adoptado o Enquadramento comunitário dos auxílios estatais a favor do ambiente (2008/C 82/01). No momento em que escrevemos este artigo, aguarda-se a publicação do documento que enquadrará os auxílios estatais a favor da protecção do ambiente e da energia entre 2014-2020. Este documento contém alterações importantes no sector dos biocombustíveis, restringindo a possibilidade de se concederem apoios aos biocombustíveis de primeira geração (cfr. infra 2.1. Gerações de biocombustíveis).

${ }^{26}$ Sobre este assunto, cfr. DelvauX, B. - Promoting Biofuels in Energy Supply..., pp. 73 e ss.
} 
desenvolvidos e, dentro destes, as populações menos favorecidas, os que mais sofreram com a globalização dos riscos da produção dos biocombustíveis. Compreendem-se, por essa razão, as acusações de que a política europeia de biocombustíveis começou a ser alvo. No domínio ambiental, foi acusada de desflorestação, destruição de habitats, pressão sobre recursos os recursos hídricos, erosão e perda de produtividade dos solos, e incremento do uso de agro-tóxicos. No plano social, surgiram alertas para as condições de trabalho inadequadas em que, muitas vezes, os biocombustíveis são produzidos. Em todo o caso, a acusação mais significativa foi, sem dúvida, a de que a produção de biocombustíveis ameaça a segurança alimentar, constituindo mesmo, segundo alguns autores, um crime contra humanidade $e^{27}$. A urgência em dar resposta a estas críticas conduziu às alterações introduzidas pela Directiva das Energias Renováveis ${ }^{28}$.

\subsection{Viragem rumo à sustentabilidade}

A principal novidade trazida pela Directiva das Energias Renováveis foi a consagração dos critérios de sustentabilidade ${ }^{29}$. Estes critérios devem ser respeitados tanto pelos biocombustíveis produzidos no território dos Estados-membros como por aqueles que sejam importados de países que não pertencem à União Europeia. O cumprimento destes critérios é importante na medida em que constitui uma condição indispensável para que os biocombustíveis sejam considerados sustentáveis e, consequentemente, possam: (i) ser contabilizados para efeitos do cumprimento das metas estabelecidas pela União em matéria de energias renováveis; e (ii) beneficiar de eventuais regimes de apoio ${ }^{30}$.

Apesar de a Directiva das Energias Renováveis não ter a preocupação de consagrar expressamente uma tal divisão, é importante distinguir os critérios de sustentabilidade ambiental dos critérios de sustentabilidade social. Em termos genéricos, pode dizer-se

\footnotetext{
${ }^{27}$ Esta acusação pertence a Jean Ziegler, autor do relatório The Right to Food, de 22 de Agosto de 2007.

28 Os critérios de sustentabilidade previstos na Directiva das Energias Renováveis, estão também consagrados no art. 7. ${ }^{\circ}$-B da Directiva 2009/30/CE, de 23 de Abril de 2009, que altera a Directiva 98/70/CE no que se refere às especificações da gasolina e do gasóleo rodoviário e não rodoviário e à introdução de um mecanismo de monitorização e de redução das emissões de gases com efeito de estufa e que altera a Directiva 1999/32/CE do Conselho no que se refere às especificações dos combustíveis utilizados nas embarcações de navegação interior e que revoga a Directiva 93/12/CEE.

${ }^{29}$ Cfr. art. $17 .^{\circ}$ da Directiva das Energias Renováveis.

${ }^{30}$ Cfr. art. 17.\%1 da Directiva das Energias Renováveis. Ver também o ponto 3.1.6. do Enquadramento comunitário dos auxílios estatais a favor do ambiente (2008/C 82/01): "Os auxílios ao investimento e/ou ao funcionamento para a produção de biocombustíveis devem ser apenas autorizados no que se refere aos biocombustíveis sustentáveis".
} 
que os primeiros respeitam directamente à protecção de um determinado bem ambiental, enquanto os segundos se reportam essencialmente à salvaguarda de direitos humanos. Analisemos cada uma destas categorias de critérios.

\subsubsection{Critérios de sustentabilidade ambiental}

Os critérios de sustentabilidade ambiental previstos na Directiva das Energias Renováveis incidem essencialmente sobre três domínios: (i) o nível de redução de emissões de gases com efeito de estufa; (ii) a adequação ambiental dos terrenos de que provêm as matérias-primas utilizadas na produção de biocombustíveis ${ }^{31}$; e (iii) as práticas agrícolas levadas a cabo para produzir as matérias-primas utilizadas na concepção dos biocombustíveis.

No que respeita ao nível de redução de emissões de gases com efeito de estufa, a Directiva das Energias Renováveis impõe que se cumpra um patamar/nível mínimo de redução de emissões. A ideia subjacente a este critério é a seguinte: atendendo aos custos e aos potenciais impactos negativos da produção de biocombustíveis, só deve ser fomentada a produção dos biocombustíveis que reduzem significativamente as emissões de gases com efeito de estufa. Este patamar mínimo de redução de emissões vai aumentando progressivamente e é mais elevado para as instalações que tenham entrado em funcionamento mais tarde. Até 31 de Dezembro de 2016, impõe-se que os biocombustíveis atinjam uma redução das emissões de gases com efeito de estufa de, pelo menos, $35 \%$ em comparação com os combustíveis fósseis que visam substituir, mas para as instalações que tenham entrado em funcionamento a partir de 1 de Janeiro de 2011, o nível de mínimo de redução de emissões é de 50\%. A partir de 1 de Janeiro de 2017, o nível mínimo de redução de emissões de 50\% estender-se-á a todas as instalações. Quanto às instalações que entrem em funcionamento a partir de 1 de Janeiro de 2017, impõe-se um nível mínimo de redução de emissões de 60\% a partir de 1 de Janeiro de $2018^{32}$. Para efeitos do cálculo do nível de redução de emissões de gases com efeito de estufa, é importante registar que a Directiva das Energias Renováveis impõe a contabilização das emissões que decorrem das alterações directas do uso dos solos ${ }^{33}$.

Em segundo lugar, a Directiva das Energias Renováveis determina quais os terrenos que não são ambientalmente adequados para a produção de biocombustíveis. Deste modo, não se consideram ambientalmente sustentáveis os biocombustíveis

\footnotetext{
31 A adequação ambiental dos terrenos é aferida em função do estatuto que os terrenos tenham em Janeiro de 2008 ou após essa data. Cfr. art. 17.\%/3 e 4 da Directiva das Energias Renováveis.

${ }^{32} \mathrm{Cfr}$. art. 17.\%/2 da Directiva das Energias Renováveis.

${ }^{33}$ Cfr. art. $19 .^{\circ}$ e anexo V da Directiva das Energias Renováveis.
} 
produzidos a partir matérias-primas provenientes de: (i) terrenos ricos em biodiversidade $^{34}$; e (ii) terrenos com elevado teor de carbono (incluem-se aqui as zonas húmidas, as zonas continuamente arborizadas, os terrenos com uma extensão superior a 1 hectare com árvores de mais de 5 metros de altura e um coberto florestal entre 10\% e $30 \%$ e as turfeiras $)^{35}$. O fundamento comum destas proibições é o seguinte: a produção de biocombustíveis não pode ser realizada à custa desflorestação e da destruição de habitats $^{36}$. A este fundamento comum, acrescenta-se ainda, no caso da proibição que incide sobre os terrenos com elevado teor de carbono, um fundamento específico: tendo em conta que o objectivo da promoção dos biocombustíveis é a redução de emissões de gases com efeito de estufa, devem impedir-se as conversões de usos dos solos que agravem significativamente o nível de emissões.

Além de atender ao nível de emissões e à adequação ambiental dos terrenos, a Directiva das Energias Renováveis impõe ainda que o cultivo de matérias-primas utilizadas na produção de biocombustíveis respeite os requisitos e as normas previstos pelas disposições indicadas sob o título "Ambiente" do anexo II, parte A e n. ${ }^{\circ}$ 9, do Regulamento (CE) n. ${ }^{\text {7 } 73 / 2009}$ do Conselho, de 19 de Janeiro ${ }^{37}$, e de acordo com os requisitos mínimos de boas condições agrícolas e ambientais, nos termos do art. 6.\%/1 do mesmo Regulamento ${ }^{38}$. Consequentemente, só se consideram sustentáveis os biocombustíveis convertidos a partir de matérias-primas produzidas em condições agrícolas que sejam amigas do ambiente. Os agricultores são, assim, obrigados a respeitar normas relativas à protecção dos solos, à conservação dos níveis de matéria orgânica do solo, à preservação dos habitats, e à protecção e gestão da água. O respeito deste requisito é particularmente importante porque a utilização de certos fertilizantes pode interferir no nível de emissões de gases com efeito de estufa. Utilizando um exemplo referido num relatório da Comissão Europeia, recordamos que a utilização de

\footnotetext{
${ }^{34}$ Cfr. art. $17 . \% / 3$ da Directiva das Energias Renováveis.

${ }^{35} \mathrm{Cfr}$. art. 17.\%/4 da Directiva das Energias Renováveis.

${ }^{36}$ Segundo o considerando n. ${ }^{\circ} 69$ da Directiva das Energias Renováveis, seria moralmente inaceitável para os consumidores da União que o incremento da produção e consumo de biocombustíveis tivesse como resultado a destruição da biodiversidade.

É, no entanto, curioso que a Directiva das Energias Renováveis se tenha lembrado de invocar a moralidade dos consumidores europeus no contexto da protecção dos terrenos ricos em biodiversidade e não tenha considerado também moralmente inaceitável que o aumento da utilização dos biocombustíveis pudesse ter como efeito a morte de milhares de pessoas em consequência do aumento do preço dos géneros alimentícios.

${ }^{37}$ O Regulamento (CE) n. ${ }^{\circ}$ 73/2009 do Conselho, de 19 de Janeiro, estabelece regras comuns para os regimes de apoio directo aos agricultores no âmbito da política agrícola comum e institui determinados regimes de apoio a favor dos agricultores.

${ }^{38}$ Cfr. art. 17.\% da Directiva das Energias Renováveis.
} 
adubos pode originar emissões de óxido nitroso, cujo potencial para o aquecimento global é muito superior ao das emissões de dióxido de carbono que se pretendem evitar $^{39}$.

\subsubsection{Critérios de sustentabilidade social}

A consagração dos critérios de sustentabilidade social revelou-se bem mais controversa do que a dos critérios de sustentabilidade ambiental. Com efeito, a intenção de consagrar critérios sociais foi expressamente afastada pela própria Comissão Europeia com fundamento na sua incompatibilidade com as normas da Organização Mundial do Comércio (OMC). Deste modo, o art. $15^{\circ}$ da proposta de directiva apresentada pela Comissão ${ }^{40}$ - que corresponde ao actual art. $17 .^{\circ}$ da Directiva das Energias Renováveis -, não fazia qualquer referência a critérios de sustentabilidade social, versando exclusivamente sobre os critérios de sustentabilidade ambiental, como indiciava a própria epígrafe do preceito: "Critérios de sustentabilidade ambiental para os biocombustíveis e outros biolíquidos" (sublinhado nosso). As únicas referências à consideração dos efeitos sociais da política europeia de biocombustíveis encontravamse no art. $20 .^{\circ}$, em que já se previa a obrigação de realizar relatórios periódicos.

$\mathrm{O}$ art. $15 .^{\circ}$ da proposta da Comissão sofreu, no entanto, alterações profundas ao longo do procedimento de aprovação da directiva, dando origem ao actual art. $17 .^{\circ}$. A revisão da epígrafe do artigo é sintomática das alterações introduzidas: "Critérios de sustentabilidade para os biocombustíveis e outros biolíquidos”. O art. 17. ' da Directiva das Energias Renováveis já não se refere exclusivamente a critérios de sustentabilidade ambiental como sucedia no art. $15 .^{\circ}$ da proposta da directiva, impondo a realização de relatórios sobre um conjunto de efeitos sociais resultantes da política europeia de biocombustíveis $^{41}$. Deste modo, a Comissão Europeia fica, desde logo, incumbida de apresentar de dois em dois anos um relatório sobre: (i) o impacto do aumento da procura dos biocombustíveis na sustentabilidade social da União e dos países terceiros; e (ii) o impacto da política de biocombustíveis da União Europeia na disponibilidade de

\footnotetext{
${ }^{39}$ COM (2006) 845 final, 10.01.2007, Relatório sobre o Progresso em Biocombustíveis, p. 10.

${ }^{40}$ COM (2008) 19 final, 23.01.2008, Proposta de Directiva do Parlamento Europeu e do Conselho relativa à promoção da utilização de energia proveniente de fontes renováveis.

${ }^{41}$ A obrigação de apresentar relatórios sobre os impactos sociais da política europeia de biocombustíveis foi consagrada na sequência de uma proposta realizada pela COMISSÃo DO AMBIENTE, DA SAÚDE E DA SEgurAnÇA AlimentAR, 15.07.2008, Parecer sobre a proposta de directiva do Parlamento Europeu e do Conselho relativa à promoção da utilização de energia proveniente de fontes renováveis (COM(2008)0019 - C6-0046/2008 - 2008/0016(COD)), p. 8.
} 
géneros alimentícios a um preço acessível, designadamente para as pessoas que vivem em países em vias de desenvolvimento ${ }^{42}$.

Além disso, os relatórios devem conter informações relativas aos direitos de uso do solo $^{43}$. Neste contexto, parece-nos que a Comissão deverá, por exemplo, incluir nos seus relatórios informações sobre a disponibilidade de terras agrícolas para as pessoas que vivem nos países em vias de desenvolvimento. Este tipo de informação é particularmente relevante porque um dos problemas levantados pela produção de biocombustíveis nos países em vias de desenvolvimento é o apoderamento das terras por empresas multinacionais, ameaçando a disponibilidade de géneros alimentícios para a população local, cuja principal fonte de rendimento é a actividade agrícola. A este problema acresce um outro que é o do respeito dos direitos de povos indígenas que, vivendo em determinados territórios desde tempos ancestrais, não têm qualquer título que ateste o seu direito propriedade sobre essas mesmas terras. Este fenómeno de apoderamento das terras por parte de empresas multinacionais costuma ser designado de "land grabbing" e tem-se tornado uma prática tão frequente como preocupante em muitos países africanos ${ }^{44}$. Como veremos mais à frente (cfr. infra 2.5. Direitos de uso do solo), este será um dos aspectos em que a Directiva das Energias Renováveis poderá sofrer alterações muito significativas.

Finalmente, a Comissão Europeia é ainda obrigada a reportar dados relativos à ratificação e aplicação de várias convenções internacionais por países terceiros que representem uma fonte significativa de matérias-primas para a produção de biocombustíveis consumidos no União Europeia. Relativamente às condições sociais laborais que envolvem a produção de biocombustíveis, destacam-se as seguintes convenções da Organização Internacional do Trabalho: Convenção sobre o Trabalho Forçado (n. ${ }^{\circ}$ 29); Convenção sobre a Liberdade Sindical e a Protecção do Direito Sindical (n. ${ }^{\circ}$ 87); Convenção sobre a Aplicação dos Princípios do Direito e Negociação Colectiva (n. ${ }^{\circ}$ 98); Convenção sobre a Igualdade de Remuneração entre a Mão-de-Obra Masculina e a Mão-de-Obra Feminina em Trabalho de Igual Valor (n. $\left.{ }^{\circ} 100\right)$; Convenção

\footnotetext{
${ }^{42}$ Cfr. art. 17.\%/7 da Directiva das Energias Renováveis. O art. 23.\%/2 retoma a preocupação com os efeitos da política da União Europeia sobre o preço dos géneros alimentares: “A Comissão deve estar particularmente atenta, neste contexto, ao impacto que a produção dos biocombustíveis poderá ter sobre os preços dos géneros alimentícios". E segundo o n. 8 do mesmo preceito, a Comissão deve analisar o impacto da prossecução do objectivo previsto no art. 3.\%/4 sobre a disponibilidade de géneros alimentícios a preços acessíveis.

${ }^{43}$ Cfr. arts. 17.\%/7 e 23.\% da Directiva das Energias Renováveis.

${ }^{44}$ Sobre este assunto, consultar MATONDI, P. B; HAVNEVIK, K.; BEYENE, A. - Biofuels, land grabbing and food security in Africa. London - New York: Zed Books, 2011.
} 
sobre a Abolição do Trabalho Forçado (n. ${ }^{\circ}$ 105); Convenção sobre a Discriminação no Emprego e na Profissão (n. ${ }^{\circ}$ 111); Convenção sobre a Idade Mínima de Admissão ao Emprego (n. ${ }^{\circ} 138$ ); Convenção sobre a Interdição das Piores Formas de Trabalho das Crianças e a Acção Imediata com vista à sua Eliminação (n. $\left.{ }^{\circ} 182\right)^{45}$.

\subsubsection{Utilidade dos critérios de sustentabilidade}

A intenção de não contrariar as normas da OMC teve consequências ao nível da densidade dos critérios de sustentabilidade. Os critérios de sustentabilidade social não têm a mesma densidade que os critérios de sustentabilidade ambiental. Verificar se determinado biocombustível foi convertido a partir de matérias-primas produzidas num terreno ambientalmente adequado, não é o mesmo que determinar o impacto da política europeia de biocombustíveis no preço dos géneros alimentícios, tendo em conta a complexa teia de factores que interfere na variação do preço destes bens. Além disso, a densidade dos próprios critérios de sustentabilidade social também é variável: determinar se um país ratificou e aplicou a Convenção sobre a Igualdade de Remuneração entre a Mão-de-Obra Masculina e a Mão-de-Obra Feminina em Trabalho de Igual Valor (n. ${ }^{\circ}$ 100), também não é a mesma coisa que determinar o impacto da política europeia de biocombustíveis no preço dos géneros alimentícios.

Esta heterogeneidade no plano densificatório explica o levantamento de algumas dúvidas quanto à utilidade de alguns critérios de sustentabilidade social. Desde logo, afigura-se discutível a utilidade da obrigação que impende sobre a Comissão de elaborar relatórios periódicos que acompanhem o impacto social da política europeia de biocombustíveis. Em todo o caso, não existindo uma obrigação genérica desta natureza para aquisição de outros bens e serviços pela União Europeia ao resto do mundo, parece-nos que esta obrigação é, no mínimo, um passo importante no sentido de atender aos impactos sociais da produção dos biocombustíveis. A relevância destes relatórios depende, no entanto, das consequências que os mesmos tenham na configuração da política europeia de biocombustíveis: em que termos é que as conclusões dos relatórios afectarão os fluxos comerciais internacionais de biocombustíveis? Se um Estado não respeitar uma determinada convenção internacional cujo cumprimento é exigido pela

\footnotetext{
${ }^{45}$ Para além destas Convenções, a Directiva das Energias Renováveis menciona também: o Protocolo de Cartagena sobre Biossegurança; e a Convenção sobre o Comércio Internacional de Espécies da Fauna e da Flora Selvagens Ameaçadas de Extinção.
} 
directiva, deixarão de ser sustentáveis os biocombustíveis nele produzidos? E, finalmente, se se verificar que o impacto sobre o preço dos géneros alimentícios é demasiado elevado, deverá pôr-se fim à política europeia de promoção de biocombustíveis? A Directiva das Energias Renováveis não estabelece nenhuma sanção para as situações apresentadas, mas consagra expressamente o dever de a Comissão propor medidas correctivas no caso de se verificarem impactos significativos nos domínios acabados de enunciar ${ }^{46}$. É neste contexto que devem ser compreendidas as alterações que se avizinham.

\section{Futuro próximo da política europeia de biocombustíveis}

O procedimento de revisão da Directiva das Energia Renováveis encontra-se, actualmente, em curso, prevendo-se que a sua conclusão ocorra até ao final de 2014. Uma grande parte das alterações é motivada pela necessidade de rever os critérios de sustentabilidade, tendo em consideração os estudos científicos realizados depois da aprovação da Directiva das Energias Renováveis. Entre outros aspectos, foi dada particular atenção ao impacto das alterações indirectas da utilização dos solos $^{47}$ nas emissões de gases com efeito de estufa. $\mathrm{Na}$ verdade, alguns estudos sugerem que as alterações indirectas da utilização dos solos podem anular as reduções de emissões obtidas por determinados biocombustíveis. Perante a incerteza e as limitações dos actuais modelos de quantificação dos efeitos das alterações indirectas da utilização dos solos, a Comissão Europeia adoptou uma abordagem precaucionária (precautionnary approach) e decidiu apresentar propostas de alteração da Directiva das Energias Renováveis em que se vislumbra a intenção de limitar a contribuição dos biocombustíveis de primeira geração e aumentar as bonificações atribuídas aos biocombustíveis de segunda e terceira geração. Para facilitar a compreensão das alterações que se pretendem introduzir, começaremos por identificar os biocombustíveis que integram cada uma das gerações e, num segundo momento, analisaremos detalhadamente as propostas apresentadas em relação a cada uma delas.

\footnotetext{
${ }^{46}$ Cfr. último parágrafo do art. 17.\%/7 da Directiva das Energias Renováveis.

47 As alterações indirectas da utilização dos solos ocorrem quando a produção de biocombustível em terras agrícolas já existentes desloca a produção de outras culturas que, por sua vez, conduzem à conversão de solos em terras agrícolas. Em contraposição, as alterações directas ocorrem quando a obtenção de matérias-primas destinadas à produção de biocombustíveis se realiza em solos que "inicialmente tinham um estatuto diferente e foram directamente convertidos em terras agrícolas" (cfr. COM (2010) 811final, 22.12.2010, Relatório da Comissão sobre as alterações indirectas da utilização dos solos relativas aos biocombustíveis e aos biolíquidos, p. 4).
} 


\subsection{Gerações de biocombustíveis}

No conceito de biocombustível inclui-se todo o combustível obtido a partir da conversão da biomassa ${ }^{48}$. No entanto, atendendo à matéria-prima utilizada, admite-se a existência várias gerações de biocombustíveis: primeira geração, segunda geração e terceira geração ${ }^{49}$.

Os biocombustíveis de primeira geração são aqueles que são produzidos a partir das culturas de açúcar e de amido que são convertidos em etanol (conversão biológica através de fermentação), e das culturas que contêm óleo que é aproveitado para produzir biodiesel (conversão química) ${ }^{50}$. Tratando-se de biocombustíveis produzidos a partir de matérias-primas susceptíveis de serem direccionados para o sector alimentar (ex: milho, trigo,...), compreende-se que sejam acusados de ameaçarem a segurança alimentar e questionados enquanto instrumento de redução das emissões dos gases com efeito de estufa.

Diferentemente, os biocombustíveis de segunda geração não são produzidos a partir de matérias-primas susceptíveis de serem destinadas à alimentação. Trata-se de biocombustíveis "obtidos a partir de recursos não alimentares e compreendem duas fileiras, a primeira sendo a conversão lenhocelulósica em etanol por via biológica, e a segunda a conversão da biomassa em combustíveis por via termoquímica" ${ }^{51}$. Este tipo

\footnotetext{
${ }^{48}$ Cfr. art. 2.\% i) da Directiva das Energias Renováveis. O conceito de biomassa é fornecido pelo art. $2 . \%$ ) da mesma directiva: "a fracção biodegradável de produtos, resíduos e detritos de origem biológica provenientes da agricultura (incluindo substâncias de origem vegetal e animal), da exploração florestal e de indústrias afins, incluindo da pesca e da aquicultura, bem como a fracção biodegradável dos resíduos industriais e urbanos".

49 Existem mesmo autores que entendem que se pode falar ainda de uma quarta geração de biocombustíveis.

${ }^{50}$ A propósito da definição de biocombustíveis de primeira geração, cfr. JOHNSON, F. X.; VIRGIN, I. Future Trends in Biomass Resources for Food and Fuel. In Rosillo-CAlle, F.; Johnson, F. X. - Food versus Fuel: an Informed Introduction to Biofuels. London - New York: Zed Books, 2010, pp. 178-179; e SMITH, J. - Biofuels and the Globalization of Risk: the biggest change in North-South relationship since colonialism?. London - New York: Zed Books, 2010 pp. 19-20. Em língua portuguesa, consultar Carvalho, D. W.; Leite, J. R. M.; Caetano, M. A. - Sociedade de risco, mudanças climáticas e biocombustíveis. In FERREIRA, H. S.; LEITE, J. R. M. - Biocombustíveis - fonte de energia sustentável?: considerações jurídicas, técnicas e éticas. São Paulo: Editora Saraiva, 2010, p. 28.

51 A citação apresentada resulta da tradução livre de um texto de ELST, R. - Les défis de la nouvelle directive sur les énergies renouvelables et son impact sur le commerce intra- et extracommunautaire. In Buschle, D ; HiRsbrunner, S. ; KAdDOus, C. - European Energy Law/ Droit Européen de l'Énergie. Helbing Lichtenhahn, 2011, p. 195. Com efeito, existem no âmbito da segunda geração de biocombustíveis duas grandes categorias de biocombustíveis que se distinguem pelo método de conversão: bioquímico ou térmico-químico. A conversão bioquímica produz etanol lenhocelulósico. A conversão térmico-química é feita através do método Fischer-Tropsch biomass-to-liquids (BTL) e pode dar origem a diversos tipos de combustível (combustíveis para aviões, combustíveis que substituem o petróleo e o diesel). $\mathrm{O}$ etanol lenhocelulósico tem a vantagem de poder ser usado separadamente para o aquecimento e para a produção de energia, enquanto o BTL pode ser convertido em gás. Cfr. JOHNSON, F.
} 
de biocombustíveis não concorre directamente com o sector alimentar, mas poderá competir indirectamente por via da utilização de solos e recursos hídricos que, de outro modo, poderiam ser orientados para a produção de géneros alimentícios.

Os biocombustíveis de terceira geração, por seu turno, são os produzidos a partir de microorganismos como, por exemplo, as microalgas ${ }^{52}$. Este tipo de biocombustíveis apresenta mais vantagens ambientais não só porque tem um rendimento energético mais elevado, mas também porque pode ser produzido em ambiente aquático, evitando, assim, potenciais conflitos relativos aos usos do solo ${ }^{53}$. Além disso, produção de biocombustíveis a partir de algas poderá ter vantagens ao nível do aproveitamento de águas não tratadas ${ }^{54}$. Finalmente, os biocombustíveis de terceira geração permitem não só substituir o petróleo mas também o hidrogénio ${ }^{55}$.

Uma vez identificados os biocombustíveis pertencentes a cada uma das gerações, vejamos agora as propostas de alteração da Directiva das Energias Renováveis apresentadas relativamente a cada uma delas.

\subsection{Moldura da contribuição dos biocombustíveis}

Os biocombustíveis de primeira geração são, como vimos acima, aqueles cujos potenciais impactos ambientais e sociais são mais elevados. Compreende-se, por essa razão, que a proposta de alteração apresentada pela Comissão Europeia tenha procurado limitar o contributo deste tipo de biocombustíveis para o cumprimento das metas energéticas previstas até 2020. Para esse efeito, a proposta inicial da Comissão Europeia introduziu a seguinte medida: a contribuição dos biocombustíveis de primeira geração não poderá ser superior a $5 \%$ do consumo final de energia nos transportes em $2020^{56}$. Isto significa que só metade do objectivo estabelecido para 2020 (10\% de energias renováveis no sector dos transportes) poderá ser atingido à custa da utilização de biocombustíveis de primeira geração, devendo a outra metade ser alcançada com

X.; VIRGIN, I. - Future Trends in Biomass Resources for Food and Fuel..., p. 180; e SMITH, J. - Biofuels and the Globalization of Risk..., pp. 20-21. Na literatura em língua portuguesa, confrontar também Carvalho, D. W.; Leite, J. R. M.; Caetano, M. A. - Sociedade de risco, mudanças climáticas e biocombustíveis..., p. 29.

${ }^{52}$ Cfr. ELST, R. - Les défis de la nouvelle directive sur les énergies renouvelables..., p. 195.

${ }^{53}$ Cfr. SMith, J. - Biofuels and the Globalization of Risk..., p. 21.

${ }^{54}$ Cfr. SACHS, I. - Bioenergias: uma janela de oportunidade. In ABRAMOVAY, R. - Biocombustíveis: a energia da controvérsia, São Paulo: Editora Senac, 2009, p. 170.

${ }^{55}$ Cfr. Johnson, F. X.; VIRGIN, I. - Future Trends in Biomass Resources for Food and Fuel..., pp. 181182.

${ }^{56}$ Cfr. o art. 3.\% $/ 1$ e 4/d da Proposta da Comissão. 
recurso a biocombustíveis de segunda e terceira geração ou outros combustíveis renováveis.

No projecto de resolução apresentado pelo Parlamento Europeu, propôs-se, no entanto, que este limite deveria situar-se num valor ligeiramente superior: $5,5 \%{ }^{57}$. Apesar de parecer pouco em termos percentuais, esta alteração não é insignificante. Ela implica que o contributo dos biocombustiveis de primeira geração para efeitos do cumprimento das metas de 2020 passe dos $50 \%$ para os 55\%. Esta proposta do Parlamento Europeu é, sem dúvida, mais gravosa para o ambiente mas pode justificar-se por duas razões: (i) a consciência da dificuldade de atingir a meta de consumo de energias renováveis fixada para 2020, respeitando o limite de contribuição de $50 \%$ proposto pela Comissão; e (ii) a necessidade de compensar a proposta de restrição das bonificações concedidas aos biocombustíveis de segunda e terceira geração apresentada pelo Parlamento (ver infra 2.3. Bonificações).

Em contrapartida, o projecto do Parlamento prevê também que "a quota de energia dos biocombustíveis avançados enumeradas no anexo IX, partes A e C, deve representar, pelo menos, $2 \%$ do consumo final de energia no sector dos transportes em $2020^{\prime, 58}$. Este limite mínimo de contribuição aplica-se a determinados biocombustíveis de segunda e terceira geração como, por exemplo, os que são obtidos a partir de algas ou bactérias.

\subsection{Bonificações}

A Comissão não se ficou pela introdução de uma moldura de contribuição dos biocombustíveis. A essa moldura foi acrescentado um conjunto de bonificações dirigidas aos biocombustíveis de segunda e terceira geração, premiando, assim, os biocombustíveis com menores impactos ambientais e sociais ${ }^{59}$. Em rigor, a ideia de discriminar positivamente os biocombustíveis mais "amigos do ambiente" não é nova, existindo já bonificações para os biocombustíveis produzidos a partir de resíduos e de

\footnotetext{
${ }^{57}$ Cfr. alteração 81 do Projecto de Resolução Legislativa do Parlamento Europeu, sobre a proposta de directiva do Parlamento Europeu e do Conselho que altera a Directiva 98/70/CE, relativa à qualidade da gasolina e do combustível para motores diesel, e a Directiva 2009/28/CE, relativa à promoção da utilização de energia proveniente de fontes renováveis (Projecto de Resolução Legislativa do Parlamento Europeu).

${ }^{58}$ Cfr. alteração 81 do Projecto de Resolução Legislativa do Parlamento Europeu.

${ }^{59}$ Consultar a nova alínea $e$ do art. $4 .^{\circ}$ da Proposta da Comissão.
} 
detritos na Directiva das Energias Renováveis ${ }^{60}$. A Comissão Europeia decidiu simplesmente estender a bonificação a outros biocombustíveis de segunda e terceira geração.

Deste modo, a Comissão propôs que os biocombustíveis a produzidos a partir de (i) algas, (ii) fracção de biomassa de resíduos urbanos mistos ${ }^{61}$, (iii) fracção de biomassa de resíduos industriais, (iv) palha, (v) estrume animal e lamas de depuração, (vi) efluentes da produção de óleo de palma e cachos de frutos de palma vazios, (vii) breu de tall oil, (viii) glicerina não refinada, (ix) bagaço, (x) bagaço de uvas e borras de vinho, (xi) cascas de frutos secos, (xii) peles, (xiii) carolos, e (xiv) cascas, ramos, folhas, serradura e aparas, são considerados como tendo quatro vezes o seu teor energético. Para além disso, são ainda bonificados os biocombustíveis produzidos a partir de (i) óleos alimentares usados, (ii) gorduras animais ${ }^{62}$, (iii) materiais celulósicos não alimentares, e (iv) material lignocelulósico (com excepção dos toros para serrar e madeira para folhear), que são considerados como tendo duas vezes o seu teor energético.

No seu projecto de resolução, o Parlamento Europeu veio, todavia, restringir a possibilidade de os biocombustíveis serem considerados como tendo quatro vezes o seu teor energético aos casos em que os mesmos sejam produzidos a partir de algas (autotróficas) ou de bactérias ${ }^{63}$.

\subsection{Nível mínimo de redução de emissões}

Outro dos aspectos que a Comissão Europeia pretende alterar é o critério de sustentabilidade ambiental relativo ao nível mínimo de redução de emissões de gases com efeito de estufa. Neste âmbito, a Comissão adoptou um comportamento ambivalente.

\footnotetext{
${ }^{60}$ Cfr. art. 21.\%/2 da Directiva das Energias Renováveis.

${ }^{61}$ Excluem-se os resíduos domésticos separados sujeitos a objectivos de reciclagem nos termos do art. 11.\%/2/a da Directiva 2008/98/CE, de 19 de Novembro, relativa aos resíduos e que revoga certas directivas.

${ }^{62}$ Consideram-se, para este efeito, as gorduras animais classificadas nas categorias I e II de acordo com o disposto no Regulamento (CE) n. ${ }^{\circ} 1774 / 2002$, que estabelece regras sanitárias relativas aos subprodutos animais não destinados ao consumo humano.

${ }^{63}$ Cfr. alterações 82 e 121 do Projecto de Resolução Legislativa do Parlamento Europeu.
} 
Por um lado, o nível mínimo de redução de emissões para as instalações que entrem em funcionamento $^{64}$ depois de 1 de Julho de 2014 deve passar para os $60 \%$, antecipando-se, assim, o limiar mínimo de $60 \%$ que, de acordo com a Directiva das Energias Renováveis, só deveria aplicar-se a instalações que entrassem em funcionamento a partir de 1 de Janeiro de 2017. Esta alteração vai, portanto, no sentido de um maior comprometimento ambiental da política europeia de biocombustíveis.

Por outro lado, em relação a instalações que entrem em funcionamento até 1 de Julho de 2014, propõe-se que o limiar mínimo de redução de emissões seja de $35 \%$ até 31 de Dezembro de 2017, e de $50 \%$ a partir de 1 de Janeiro de $2018^{65}$. Esta proposta da Comissão pretende, portanto, adiar o cumprimento do limiar mínimo de redução de emissões de 50\% que, de acordo com a Directiva das Energias Renováveis, se deveria aplicar a partir de 1 de Janeiro de $2017^{66}$. Ao invés do que sucede na proposta de alteração referida no parágrafo anterior, existe aqui um claro intuito de suavizar o cumprimento um critério de sustentabilidade ambiental. É provável que o fundamento desta proposta de alteração seja a constatação da dificuldade prática de os operadores económicos respeitarem o requisito referido dentro do prazo fixado na Directiva das Energias Renováveis. Em todo o caso, sempre se pode levantar a questão de saber se não estaremos aqui perante uma proposta que viola o princípio jurídico-ambiental da proibição do retrocesso ambiental ${ }^{67}$.

\footnotetext{
${ }^{64}$ A proposta define expressamente o que deve entender-se por "entrado em funcionamento": momento a partir do qual uma instalação procede à produção física de biocombustíveis ou biolíquidos.

${ }^{65}$ Cfr. o n. ${ }^{\circ} 2$ do art. 17. ${ }^{\circ}$ da Proposta da Comissão.

${ }^{66} \mathrm{Cfr}$. art.17.\%/2 da Directiva das Energias Renováveis.

${ }^{67}$ Abordando a urgência de reconhecer o princípio da proibição do retrocesso no domínio ambiental, cfr. PRIEUR, M. - De l'urgente nécessité de reconnaître le principe de 'non-régression' en droit de l'environnement. In Michelot, A. - Équité et Environnement: Quel(s) modèle(s) de justice environnementale ?. Bruxelles: Éditions Larcier, 2012, pp. 71 e ss.

$\mathrm{Na}$ doutrina nacional, confrontar o recente estudo de ARAGão, A. - Desenvolvimento sustentável em tempo de crise e maré de simplificação. Fundamento e limites da proibição de retrocesso ambiental. In CORReia, F; MAChADO, J.; LOUREIRO, J. (org.) - Estudos em Homenagem ao Professor Doutor José Joaquim Gomes Canotilho. Vol. IV: Administração, Sustentabilidade: entre Risco(s) e Garantia(s). Coimbra Editora, 2012, pp. 43 e ss.

Uma vez que a promoção de biocombustíveis tem, na União Europeia, um objectivo predominantemente ambiental - a redução de emissões de gases com efeito de estufa -, poderia pensar-se que as limitações à produção e utilização de biocombustíveis constituiriam um retrocesso ambiental. No entanto, estas limitações relacionam-se com a imposição de critérios de sustentabilidade ambiental que são eles próprios um factor de elevação do nível de protecção ecológica, não existindo, portanto, um retrocesso ambiental.

De todo o modo, ainda que as limitações não impliquem uma elevação do nível de protecção ecológica pense-se, por exemplo, em eventuais limitações que venham a ser impostas em virtude da necessidade de salvaguardar a segurança alimentar nos países em vias de desenvolvimento - deve considerar-se que as mesmas não constituem um retrocesso ambiental, visto que se pretende dar resposta a "efeito laterais inesperados" da política de promoção da produção e utilização de biocombustíveis (cfr. ARAGão, A. Desenvolvimento sustentável em tempo de crise..., pp. 81 e 82, nota 95).
} 


\subsection{Direitos de uso do solo}

Como vimos acima (cfr. supra 1.3.2. Critérios de sustentabilidade social), a Directiva das Energia Renováveis prevê a obrigação de a Comissão Europeia apresentar relatórios contendo informações relativas aos direitos de uso do solo ${ }^{68}$. Aparentemente, o Parlamento Europeu pretende aprofundar esta questão, acrescentando uma nova alínea ao n. ${ }^{\circ} 4$ do art. 17. ${ }^{\circ}$ da Directiva das Energias Renováveis: "4-E. Os biocombustíveis e biolíquidos considerados para os fins mencionados nas alíneas a), b) e c) do n. ${ }^{0} 1$ não devem ser produzidos a partir de matérias-primas provenientes de terrenos, a não ser que os direitos legais de terceiros, no que diz respeito à utilização e ao direito de propriedade, tenham sido respeitados, nomeadamente através do seu consentimento livre, prévio e informado e com a participação das respectivas instituições representativas",69.

Se esta proposta de alteração apresentada pelo Parlamento Europeu for incluída na versão final da directiva, ela constituirá uma novidade importantíssima porque será o primeiro critério de sustentabilidade social a adquirir uma densidade idêntica à dos critérios de sustentabilidade ambiental consagrados na Directiva das Energias Renováveis. Com efeito, o desrespeito dos direitos de uso dos solos implicará directamente a insustentabilidade dos biocombustíveis produzidos a partir de matériasprimas provenientes dos terrenos em questão, algo que não decorre do actual regime jurídico que enquadra a produção dos biocombustíveis.

\subsection{Alterações indirectas de utilização dos solos}

A necessidade de ter em consideração os efeitos das alterações indirectas de utilização dos solos foi um dos principais motivos na origem do processo alteração da Directiva das Energias Renováveis. Por essa razão, foi com alguma surpresa que constatámos que a Comissão Europeia não inseriu na sua proposta uma alteração no sentido de considerar as emissões resultantes das alterações indirectas de utilização dos solos para efeitos do cálculo da redução de emissões de gases com efeito de estufa. $\mathrm{Na}$ verdade, ao percorrermos a proposta da Comissão, percebemos que a única alteração neste domínio consiste na previsão de uma obrigação de comunicar o valor das

\footnotetext{
${ }^{68}$ Cfr. arts. $17 . \% / 7$ e 23.\% $/ 1$ da Directiva das Energias Renováveis.

${ }^{69}$ Cfr. alteração 96 do Projecto de Resolução Legislativa do Parlamento Europeu.
} 
emissões de gases com efeito de estufa resultantes de alterações indirectas de utilização dos $\operatorname{solos}^{70}$.

Para encontrar alterações relevantes neste domínio, é necessário consultar o projecto de resolução do Parlamento Europeu que pretende reformular o art. $19 .^{\circ}$ no sentido de o cálculo da redução das emissões de gases com efeito de estufa resultante da utilização de biocombustíveis ter em consideração as "estimativas de emissões decorrentes de alterações indirectas do uso do solo",71.

Além disso, o Parlamento Europeu propôs ainda o aditamento de uma nova alínea ao n. 4 do art. $17 .^{\circ}$ da Directiva das Energias Renováveis: “4-D. Os biocombustíveis e biolíquidos considerados para efeitos das alíneas a), b) e c) do n. $^{\circ} 1$ não podem ser produzidos a partir de matérias-primas provenientes de plantações florestais, como talhadias de rotação curta e florestas de rotação curta, até ser fixado um valor específico para as alterações indirectas do uso do solo relativamente ao material lignocelulósico para efeitos de cálculo do impacto dos biocombustíveis e biolíquidos nos gases com efeito de estufa, em conformidade com o artigo 19. ${ }^{0,72}$. Esta proposta é mais um reflexo da abordagem precaucionária do Parlamento Europeu perante a falta de dados relativos às emissões resultantes das alterações indirectas da utilização dos solos. Assim, enquanto não forem determinados os valores das emissões provocadas pelas alterações indirectas do uso do solo, não se considerarão sustentáveis os biocombustíveis produzidos a partir de matérias-primas provenientes de plantações florestais, como talhadias de rotação curta e florestas de rotação curta.

\footnotetext{
${ }^{70}$ Cfr. Proposta de Comissão, em particular, o aditamento do novo n. ${ }^{\circ} 6$ do art. $7 .^{\text {o }}$-A da Directiva 98/70/CE, relatica à qualidade da gasolina e do combustível para motores a diesel: "Os fornecedores de combustíveis devem, até 31 de março de cada ano, comunicar à autoridade designada pelo EstadoMembro os modos de produção de biocombustíveis, os volumes e as emissões de gases com efeito de estufa ao longo do ciclo de vida, por unidade de energia, incluindo as emissões estimadas decorrentes de alterações indiretas do uso do solo conforme definido no anexo V, e os Estados-Membros devem comunicar esses dados à Comissão".

Ver ainda o Projecto de Resolução Legislativa do Parlamento Europeu, que adita a definição de alterações directas - "qualquer mudança no uso de um terreno de uma para outra das seis categorias IPCC de ocupação do solo (terrenos florestais, terrenos de cultivo, terrenos de pastagem, zonas húmidas, povoações ou outros tipos de terrenos), para além de uma sétima categoria que inclui as culturas perenes, em particular as culturas plurianuais cujo caule não é normalmente cortado anualmente, como a talhadia de rotação curta e as palmeiras" - à Proposta da Comissão.

${ }^{71}$ Cfr. alteração 105 do Projecto de Resolução Legislativa do Parlamento Europeu.

${ }^{72}$ Cfr. alteração 95 do Projecto de Resolução Legislativa do Parlamento Europeu.
} 


\subsection{Uma abordagem positiva}

Analisando os critérios de sustentabilidade consagrados na Directiva das Energias Renováveis e as alterações que se pretendem introduzir, parece-nos que se perdeu uma oportunidade para adoptar uma abordagem positiva no contexto da classificação dos terrenos ambientalmente adequados para a produção de biocombustíveis. Como tivemos oportunidade de observar anteriormente (cfr. supra 1.3.1. Critérios de sustentabilidade ambiental), a adequação dos terrenos é delimitada negativamente, ou seja, a directiva limita-se a apresentar uma espécie de lista negra de terrenos que não devem ser aproveitados para cultivo de matérias-primas utilizadas na produção de biocombustíveis, sob pena de estes últimos serem considerados insustentáveis ${ }^{73}$.

Nesta matéria, parece-nos que deveria seguir-se o exemplo do Brasil, mais especificamente, do Estado de São Paulo. Em vez de se limitarem a elencar os terrenos ambientalmente desadequados, a Secretaria do Meio Ambiente (SMA) e a Secretaria da Agricultura e Abastecimento (SAA) do Estado de São Paulo procederam à delimitação e classificação de áreas em função da sua adequação ao desenvolvimento da cultura da cana-de-açúcar, utilizada para produzir etanol ${ }^{74}$. Assim, as áreas são classificadas em: (i) adequada; (ii) adequada com limitações ambientais; (iii) adequada com restrições ambientais; e (iv) inadequada ${ }^{75}$. Esta classificação é importante porque, no momento do licenciamento ambiental de um empreendimento, os tipos de estudo ambiental exigíveis variam consoante a área em que o interessado pretenda instalar-se ${ }^{76}$.

Um processo de classificação de áreas desta natureza, a nível europeu, não seria inédito na União Europeia. Pense-se, por exemplo, na classificação das áreas pertencentes à Rede Natura 2000. Além disso, mesmo que uma tal classificação a nível europeu se possa afigurar um processo complexo no sector dos biocombustíveis, nada impede que um Estado-membro, ou uma circunscrição administrativa, a levem a cabo por sua própria iniciativa.

\section{Comprometimento ambiental e social}

\footnotetext{
${ }^{73}$ Em rigor, existe uma pequena excepção a esta abordagem negativa. Estamos a pensar na bonificação atribuída aos biocombustíveis produzidos a partir de matérias-primas obtidas em solos degradados reconstituídos (cfr. art. 18.\%/3 e 4 e parte C do Anexo V da Directiva das Energias Renováveis).

${ }^{74}$ Cfr. Resolução Conjunta SMA-SAA, n. ${ }^{\circ}$ 4, de 18 de Setembro de 2008, que dispõe sobre o Zoneamento Agroambiental para o sector sucroalcooleiro no Estado de São Paulo.

${ }^{75}$ Cfr. art. 1. $^{\circ}$ da Resolução Conjunta SMA-SAA, n. ${ }^{\circ}$ 4, de 18 de Setembro de 2008, que dispõe sobre o Zoneamento Agroambiental para o sector sucroalcooleiro no Estado de São Paulo.

${ }^{76}$ Cfr. MoRAES, R. J. - Setor Sucroalcooleiro..., p. 90.
} 
Uma vez esboçadas as linhas gerais do regime jurídico que enquadra a produção e utilização dos biocombustíveis, importa agora reflectir sobre o grau de comprometimento ambiental e social da política europeia de biocombustíveis. Desconstruindo a pergunta que colocámos no título do presente estudo, importa responder à seguinte questão: em que sentido é que se pode dizer que a política europeia de biocombustíveis está ambiental e socialmente comprometida? Está ambiental e socialmente comprometida, no sentido em que está preocupada e empenhada na protecção do ambiente e dos direitos humanos? Ou, em vez disso, está ambiental e socialmente comprometida, no sentido em que os impactos ambientais e sociais desta política são tão significativos que o mais sensato é abandonar esta política?

\subsection{Factores de uma equação complexa}

Como qualquer fonte de energia, também os biocombustíveis têm as suas virtudes e os seus defeitos. Não existem dúvidas quanto aos potenciais impactos negativos da produção e utilização dos biocombustíveis. Mas também é verdade que os biocombustíveis são uma fonte de energia importante na transição duma economia assente no consumo de combustíveis fósseis para uma economia baseada na utilização de energias renováveis. E também não é mentira que, respeitando determinadas condições, a produção e utilização de biocombustíveis tem vantagens nos domínios ambiental, energético, socioeconómico e tecnológico.

Em termos ambientais, a utilização dos biocombustíveis contribui para o combate às alterações climáticas por via da redução de emissões de gases com efeito de estufa. Foi esta a virtude que esteve na base das medidas de promoção previstas na Directiva dos Biocombustíveis e na Directiva das Energias Renováveis.

Para além disso, a produção de biocombustíveis pode contribuir para a prevenção de riscos. Quando os biocombustíveis são produzidos, por exemplo, a partir de resíduos lenhocelulósicos derivados da limpeza de florestas, pode afirmar-se que a produção de biocombustíveis permite prevenir o risco de incêndios. Por outro lado, a prevenção de riscos pode ainda resultar da produção de biocombustíveis a partir de plantas tóxicas. Pense-se, por exemplo, no caso da produção de biocombustíveis a partir de algas tóxicas em que que se produz energia e, simultaneamente, se elimina uma planta geradora de riscos. Finalmente, a produção dos biocombustíveis pode também 
contribuir para a protecção de determinadas culturas (na Zâmbia, por exemplo, utilizase a jartropha curcas $^{77}$ ).

No plano energético, a produção de biocombustíveis permite ampliar e diversificar as fontes de aprovisionamento energético, contribuindo para incrementar a autonomia e segurança energéticas. A política europeia de biocombustíveis não tem como principal objectivo a segurança energética. Em todo o caso, este não deixa de ser um escopo importante desta política. Nos Estados-membros que possuem condições favoráveis à produção de biocombustíveis, esta pode ser uma boa alternativa porque lhes permite produzir energia a partir de recursos endógenos ${ }^{78}$.

No âmbito sócioeconómico, é importante reconhecer que a produção de biocombustíveis contribui, por um lado, para a geração de empregos nas áreas rurais que, frequentemente, são as regiões mais desfavorecidas tanto nos países desenvolvidos como nos países em vias de desenvolvimento e, por outro lado, para a criação de novos mercados para os produtos agrícolas ${ }^{79}$.

\footnotetext{
${ }^{77} \mathrm{~A}$ jartropha curcas é uma planta resistente às secas e foi trazida pelos portugueses da América do Sul para a África, sendo conhecida na Zâmbia há mais de 300 anos. Actualmente, esta planta é utilizada para a produção de biodiesel. Cfr. a este propósito CoRTEZ, L.; LEAL, M.; SinKALA, T. - Why Biofuels are Important. In Rosillo-CAlle, F.; JoHnSON, F. X. - Food versus Fuel: an Informed Introduction to Biofuels. London - New York: Zed Books, 2010, p.79.

${ }^{78}$ Ao contrário do que se possa pensar, esta pode ser uma boa alternativa mesmo para os Estados em que existe insegurança alimentar. Com efeito, se um Estado em que existe insegurança alimentar não tem as suas próprias reservas de combustíveis fósseis, isso implica que ele utilize uma parte significativa do seu orçamento para importar combustível. Ora, a energia que conseguir produzir internamente representará uma poupança que poderá ser dirigida à aquisição de bens alimentares. Por outro lado, quando cerca de 2,5 mil milhões de pessoas não têm acesso a sistemas de energia ou têm-no de forma limitada, e as áreas agrícolas e rurais dos países em vias de desenvolvimento necessitam de mais energia, a disponibilidade de biocombustíveis pode permitir aumentar a produção de alimentos. Cfr. Rosillo-CALLE, F.; TSCHIRLEY, J. - Food versus Fuel: Setting the Scene. In Rosillo-CAlle, F.; Johnson, F. X. - Food versus Fuel: an Informed Introduction to Biofuels. London - New York: Zed Books, 2010, p. 11.

Outro aspecto digno de menção prende-se com o facto de os países em vias de desenvolvimento serem exactamente aqueles que melhores condições têm para a produção de biocombustíveis. Ao contrário do que sucede com o petróleo, cuja produção está concentrada nas mãos de um reduzido número de países que se coordenam através da Organização dos Países Exportadores de Petróleo (OPEP), a produção de biocombustíveis está ao alcance de centenas de países. Existe, portanto, uma espécie de democratização energética na medida em que o poder decisório deixa de estar concentrado num número reduzido de Estados. Cfr. JANK, M. S.; NAPPO, M. - Etanol de cana-de-açúcar: uma solução energética global sob ataque. In ABRAmovay, R. - Biocombustíveis: a energia da controvérsia, São Paulo: Editora Senac, 2009 , p. 23.

${ }^{79}$ Cfr. COM (2000) 769 final, 29.11.2000, Livro Verde Para uma Estratégia Europeia de Segurança do Aprovisionamento Energético, p. 45; Rosillo-CALLE, F.; Johnson, F. X. - Introduction. In RosilloCALle, F.; Johnson, F. X. - Food versus Fuel: an Informed Introduction to Biofuels. London - New York: Zed Books, 2010, pp. 1-2; CORTEZ, L.; LEAL, M.; SinKALA, T. - Why Biofuels are Important..., p. 58.
} 
Finalmente, no domínio tecnológico, é importante sublinhar que os biocombustíveis se encontram em vantagem em relação a outras fontes de energia renováveis porque permitem utilizar tecnologia já existente ${ }^{80}$.

\subsection{Conflitos de interesses}

Ao descrevermos as virtudes da produção e utilização de biocombustíveis na União Europeia, pode ter-se criado a ilusão de que existe uma harmonia perfeita entre a prossecução dos interesses ambientais, energéticos e sócioeconómicos. Ora, nem sempre isso acontece. O mais frequente é existir uma contraposição/ colisão de interesses. E, mais do que isso, existem mesmo, por vezes, colisões entre diferentes interesses da mesma natureza. Por exemplo, o objectivo ambiental primordial da política europeia de biocombustíveis é a redução das emissões de gases com efeito de estufa. No entanto, a produção de biocombustíveis em larga escala pode ameaçar outros interesses ambientais como a protecção da biodiversidade, da floresta, dos solos, dos recursos hídricos e da qualidade do ar.

Para além disso, a produção e utilização de biocombustíveis em larga escala pode não só pôr em causa interesses ambientais, como também pode ameaçar interesses sociais. A colisão mais evidente decorre dos efeitos da produção de biocombustíveis em larga escala sobre o preço dos alimentos. No entanto, existem outras colisões mais insuspeitas. Em termos sócioeconómicos, interessa que a produção de biocombustíveis seja feita em áreas rurais da União Europeia com a participação de pequenos produtores. No entanto, a necessidade de controlar o cumprimento dos critérios de sustentabilidade implica a sujeição a sistemas de certificação ambiental cada vez mais complexos, exigentes e financeiramente insuportáveis pelos pequenos produtores ${ }^{81}$.

Outra das colisões verifica-se entre os interesses ambientais e os interesses energéticos. Em termos energéticos, a promoção dos biocombustíveis torna-se interessante porque permite diversificar e ampliar as fontes de energia ao dispor dos Estados-membros e, por esta via, aumentar a segurança do aprovisionamento energético. E quando os biocombustíveis forem produzidos a partir de matérias-primas obtidas em terrenos dos Estados-membros, esta política contribui também para

\footnotetext{
${ }^{80}$ Cfr. SMith, J. - Biofuels and the Globalization of Risk..., p. 18.

${ }^{81}$ A este propósito, ver notícia publicada na Visão: http://visao.sapo.pt/certificacao-de-biocombustiveispoe-em-risco-pequenos-produtores=f715146 (consult. 14.03.2014).
} 
aumentar autonomia energética da União Europeia, combatendo a dependência energética em face dos combustíveis fósseis. Estes interesses energéticos nem sempre se coadunam, todavia, com os interesses ambientais. Por um lado, o que faz sentido, em termos ambientais, é promover a utilização de biocombustíveis mais eficientes na redução das emissões de gases. Se esses biocombustíveis forem produzidos fora da União Europeia (ex: Argentina, Brasil, Indonésia, Moçambique...), pode dizer-se que existe um conflito potencial entre o interesse de redução de emissões e o interesse da autonomia energética. Por outro lado, a prossecução da autonomia energética pode prescindir, total ou parcialmente, do respeito pelos critérios de sustentabilidade ambiental. Para reduzir a dependência energética da União Europeia, pode fazer sentido promover a produção e utilização de biocombustíveis insustentáveis, ou seja, biocombustíveis que podem ser produzidos à custa da destruição da biodiversidade, da desflorestação, da erosão dos solos e do esgotamento dos recursos hídrico.

Por fim, podem ainda surgir colisões entre os interesses energéticos e os interesses sociais. Se a política europeia de biocombustíveis se direccionar para a redução da dependência energética, este objectivo colidirá também com o interesse da segurança alimentar nos países em vias de desenvolvimento.

\subsection{Política comprometida?}

O verdadeiro problema da política europeia de biocombustíveis foi a ausência de uma reflexão prévia em relação aos impactos ambientais e socias que a mesma poderia originar. Se essa reflexão tivesse sido realizada, não nos encontraríamos numa situação em que "andamos um passo atrás dos acontecimentos". Questões como a de saber se a promoção dos biocombustíveis é um objectivo desejável, deveriam ter sido respondidas antes de conceder auxílios estatais, de atribuir isenções e reduções fiscais, e de impor obrigações de incorporação de biocombustíveis no mercado. A ponderação das vantagens e desvantagens da política europeia de biocombustíveis deveria ter precedido a adopção de medidas de promoção da produção e consumo de biocombustíveis, de forma evitar a canalização de recursos financeiros públicos para actividades potencialmente nocivas para o ambiente. Além disso, criaram-se, entretanto, legítimas expectativas nos investidores que devem ser respeitadas, não obstante a necessidade de perseguir um nível elevado de protecção ecológica. 
Em todo o caso, atendendo às circunstâncias, seria injusto afirmar que não existe um empenho por parte da União Europeia em prevenir os impactos da produção e consumo dos biocombustíveis. O que se pode eventualmente questionar é a eficácia das medidas entretanto adoptadas para corrigir a política europeia de biocombustíveis. No fundo, a discussão à volta da política europeia de biocombustíveis pode resumir-se em duas questões. A primeira é a seguinte: a política europeia de biocombustíveis pode sobreviver apesar dos seus potenciais impactos ambientais e sociais? A resposta a esta pergunta é: depende. Se se cumprirem efectivamente os critérios de sustentabilidade ambiental e social impostos na Directiva das Energias Renováveis, parece-nos que esta política se justifica plenamente em termos ambientais. Esta resposta leva-nos à segunda questão, que é a de saber se a política europeia de biocombustíveis pode sobreviver apesar da eventual ineficácia dos critérios de sustentabilidade. Ou, perguntando de outro modo: será admissível a promoção de biocombustíveis produzidos à custa da destruição da biodiversidade, da desflorestação, da poluição atmosférica, da erosão dos solos e do esgotamento dos recursos hídricos? Será admissível a prossecução de uma política europeia de biocombustíveis à margem do ambiente? Se se verificar a ineficácia dos critérios de sustentabilidade, parece-nos indubitável que a política europeia de biocombustíveis deixará de se justificar em termos ambientais. Em consequência, restará às instâncias europeias a escolha entre a eliminação da política europeia de biocombustíveis ou a sua justificação à luz de outros objectivos como, por exemplo, a segurança energética ou a promoção do desenvolvimento do sector agrícola.

\section{Referências bibliográficas}

ARAGÃo, A. - Desenvolvimento sustentável em tempo de crise e maré de simplificação. Fundamento e limites da proibição de retrocesso ambiental. In CORREIA, F; Machado, J.; Loureiro, J. - Estudos em Homenagem ao Professor Doutor José Joaquim Gomes Canotilho. Vol. IV: Administração, Sustentabilidade: entre Risco(s) e Garantia(s). Coimbra: Coimbra Editora, 2012. ISBN 978-972-32-2054-4, pp. 43-90.

BALlerini, D.; AlazARD-TouX, N. - Les Biocarburants: état des lieux, perspectives et enjeux du développement. Paris: Editions Technip, 2006. ISBN 9782710808695. 
Carvalho, D. W.; Leite, J. R. M.; Caetano, M. A. - Sociedade de risco, mudanças climáticas e biocombustíveis. In FerreIRA, H. S.; LeITE, J. R. M. Biocombustíveis - fonte de energia sustentável?: considerações jurídicas, técnicas e éticas. São Paulo: Editora Saraiva, 2010. ISBN 978-85-02-09261-7, pp. 23-50.

CorteZ, L.; Leal, M.; Sinkala, T. - Why Biofuels are Important. In RosilloCalle, F.; Johnson, F. X. - Food versus Fuel: an Informed Introduction to Biofuels. London - New York: Zed Books, 2010. ISBN 978-1-84813-383-9, pp. 58-85.

DelvauX, B. - Promoting Biofuels in Energy Supply: the European Legal Framework. European Environmental Law Review, vol. 3, n. 3, March, 2004. ISSN 0966-1646. pp. 66-78.

ELST, R. - Les défis de la nouvelle directive sur les énergies renouvelables et son impact sur le commerce intra- et extracommunautaire. In BUSCHLE, D ; HIRSBRUNNER, S. ; Kaddous, C. - European Energy Law/ Droit Européen de l'Énergie. Helbing Lichtenhahn, 2011. ISBN 978-3-7190-3054-4, pp. 179-206.

FARIAS, T. - A Regulação dos Biocombustíveis no Âmbito Estadual. In FERREIRA, H. S.; LEITE, J. R. M. - Biocombustíveis - fonte de energia sustentável?: considerações jurídicas, técnicas e éticas. São Paulo: Editora Saraiva, 2010. ISBN 978-85-02-092617. pp. $120-137$.

Ferreira, M. L. P. C.; Ayala, P. A. - A Regulação dos Biocombustíveis no Âmbito Federal. In FerReIRA, H. S.; LeITE, J. R. M. - Biocombustíveis - fonte de energia sustentável?: considerações jurídicas, técnicas e éticas. São Paulo: Editora Saraiva, 2010. ISBN 978-85-02-09261-7, pp. 96-119.

Gomes, C. A. - Regulação dos Biocombustíveis na Comunidade Europeia. In FERREIRA, H. S.; LEITE, J. R. M. - Biocombustíveis - fonte de energia sustentável?: considerações jurídicas, técnicas e éticas. São Paulo: Editora Saraiva, 2010. ISBN 97885-02-09261-7, pp. 192-204. 
JANK, M. S.; NAPPO, M. - Etanol de cana-de-açúcar: uma solução energética global sob ataque. In ABRAmovay, R. - Biocombustíveis: a energia da controvérsia. São Paulo: Editora Senac, 2009. ISBN 978-85-7359-819-3, pp. 19-57.

Johnson, F. X.; ViRgin, I. - Future Trends in Biomass Resources for Food and Fuel. In Rosillo-Calle, F.; Johnson, F. X. - Food versus Fuel: an Informed Introduction to Biofuels. London - New York: Zed Books, 2010. ISBN 978-1-84813383-9, pp. 164-189.

LuCAS, N. J. D. - Energy and the European Communities. London: Europa Publications, 1977. ISBN 0905118146.

Matondi, P. B; HavneviK, K.; Beyene, A. - Biofuels, land grabbing and food security in Africa. London - New York: Zed Books, 2011. ISBN 978-1-84813-879-7.

MORAES, R. J. - Setor Sucroalcooleiro: regime jurídico ambiental das usinas de açúcar e álcool. São Paulo: Editora Saraiva, 2011. ISBN 978-85-02-10802-8.

PrIEUR, M. - De l'urgente nécessité de reconnaitre le principe de 'non-régression' en droit de l'environnement. In Michelot, A. - Équité et Environnement: Quel(s) modèle(s) de justice environnementale ?. Bruxelles: Éditions Larcier, 2012, ISBN 9782-8044-5166-0, pp. 71-93.

Rosillo-Calle, F.; Johnson, F. X. - Introduction. In Rosillo-Calle, F.; Johnson, F. X. - Food versus Fuel: an Informed Introduction to Biofuels. London New York: Zed Books, 2010. ISBN 978-1-84813-383-9, pp. 1-6.

Rosillo-Calle, F.; Tschirley, J. - Food versus Fuel: Setting the Scene. In Rosillo-Calle, F.; Johnson, F. X. - Food versus Fuel: an Informed Introduction to Biofuels. London - New York: Zed Books, 2010. ISBN 978-1-84813-383-9, pp. 7-28.

SACHS, I. - Bioenergias: uma janela de oportunidade. In ABRAMOVAY, R. Biocombustíveis: a energia da controvérsia. São Paulo: Editora Senac, 2009. ISBN 978-85-7359-819-3, pp. 143-181. 
SCARWELL, H-J. - Biocarburants: les temps changent! Effet d'annonce ou réelle avancée?. Villeneuve d'Ascq: Presses Universitaires du Septentrion, 2007. ISBN 9782-75740-007-4.

SMITH, J. - Biofuels and the Globalization of Risk: the biggest change in NorthSouth relationship since colonialism?. London - New York: Zed Books, 2010. ISBN 978-1-84813-570-0. 